\title{
IMPACT OF BOKO HARAM INSURGENCY ON THE SOCIOECONOMIC DEVELOPMENT OF BORNO STATE, NORTHERN NIGERIA
}

\author{
Sarki Samuel Mshelizah (Ph.D.) $)^{1}$, Solomon Binga Lezuya (Ph.D.) ${ }^{2}$ and \\ Kaka Olusegun Jimoh (Ph.D.) ${ }^{3}$
}

${ }^{1}$ Department of Political Science, Faculty of Social Sciences, Rivers State University,

Nkpolu-Oroworukwo, Port Harcourt, Rivers State, Nigeria

Email: samuelmmsarki@gmail.com

${ }^{2}$ Department of Political Science, Faculty of Social Sciences, Rivers State University,

Nkpolu-Oroworukwo, Port Harcourt, Rivers State, Nigeria

Email: lezuyabinga@yahoo.co.uk

${ }^{3}$ Department of Political Science, Faculty of Social Sciences, Rivers State University,

Nkpolu-Oroworukwo, Port Harcourt, Rivers State, Nigeria

Email: kakaolusegun74@gmail.com

Cite this article:

Sarki S.M., Solomon B.L.,

Kaka O.J. (2021), Impact of Boko Haram Insurgency on the Socioeconomic

Development of Borno State, Northern Nigeria. African

Journal of Law, Political

Research and Administration

4(1), 36-51. DOI:

10.52589/AJLPRA-

FHWNZUCK.

\section{Manuscript History}

Received: 14 March 2021

Accepted: 6 April 2021

Published: 7 May 2021

Copyright $\odot 2020$ The Author(s). This is an Open Access article distributed under the terms of Creative Commons AttributionNonCommercial-NoDerivatives 4.0 International (CC BY-NC-ND

4.0), which permits anyone to share, use, reproduce and redistribute in any medium, provided the original author and source are credited.
ABSTRACT: This study examined the impact of Boko Haram Insurgency on the socio-economic development of Borno State, Nigeria. Three research objectives, three research questions and three research hypotheses were formulated to guide this study. The study was based on the Karl Marx Theory of Violence Conflict. The study was a descriptive survey and was carried out in Borno State. A sample size of 400 respondents was determined using the Taro Yamani formula. The respondents were made up of Military personnel and civilians which were selected based on a multi-stage sampling technique. Questionnaire and Interview were the instruments used for data collection. The instrument gave high reliability of 0.84 when subjected to a reliability test using the Cronbach Alpha method. Collated data from the study were analyzed using frequency, mean, standard deviation and regression analysis. Results from this study showed that there existed a weak relationship between Boko Haram insurgency and economic activities, food, security, and educational development in Borno State. The study concluded that the Boko Haram situation demands the articulation of a comprehensive strategy and the political will to address its root causes and dangerous dynamics, focusing on inhibiting opportunities for recruitment and radicalization, and choke its financial windpipe, amongst others. The study noted that the Nigerian military has too often taken civilian casualties too easy into account. By killing citizens in the North, the population's frustration against the military increases, thereby increasing Boko Haram's appeal as an alternative. Thus, it recommended that the government should rather put its focus on the protection of civilians, witnesses and key peacemakers such as moderate Imams who preach against the insurgency.

KEYWORDS: Boko Haram, Socioeconomic Development, Insurgency, Borno State, Nigeria 


\section{INTRODUCTION}

\section{Background of the Study}

Borno State, like many other states in Northern Nigeria, has seen many attacks by the notorious Boko Haram Islamic insurgent sect that operates in that part of the country. Borno State has been revealed as the terrorist group's base of operations in recent discussions (Abinbola, 2012). The group's activities are rife with issues of insecurity, owing to the group's links to the economy, social, political, and governance, all of which have spiralling effects on the people of Borno State (Adams et al, 2014).

Nigerians welcomed the restoration of democratic rule in 1999, seeing the potential for a better future under civilian rule. As a result, the International Community lifted Nigeria's trade sanctions and other security constraints. However, as people experienced increased levels of instability, economic difficulties, and the threat of terrorism with the Boko Haram sect at the forefront, optimism quickly turned to anger. Beyond Nigeria's borders, the group has become a threat to both domestic and international security. In 2011, security forces, civilians, churches, mosques, farms, media houses, schools, and the United Nations building were all subjected to violent attacks.

The group has exacerbated several issues that the country is already dealing with, especially in the North-East. Despite the Nigerian government's attempts to contain the insurgent group, Boko Haram has evolved into a transnational danger, causing increased concern among the international community. Obviously, the repeated violent assaults have devastating consequences. The activities of the Boko Haram sect, for example, pose a significant threat to human security.

The concept of socio-economy has expanded beyond the preservation of economic activities and social processes (Agbiboa, 2014), to include the protection of citizens from diseases, hunger, unemployment, violations of human rights, displacements and housing issues, conflict, political repression, and enslavement (Agbiboa, 2014).

Scholars have interpreted and limited the comprehension and memory of the idea of protection to the security of nation-states rather than the security of citizens for many years (Danjibo, 2012). From the 1950s to the 1980s, the idea of human security began to gain traction in world politics as a result of various reports issued by several independent international commissions established by the United Nations and other regional bodies in response to growing discontent with the current conventional concept of security.

Human protection is a nebulous term with no clear or widely agreed definition; however, scholars agree that it is focused on the safety of individuals first. It is essentially an evolving philosophy that aims to address fundamental issues that threaten human beings and find longterm solutions to them by advocating that the person, rather than the state, is the first point of reference for protection.

To this end, the United Nations Development Programmes (1994) described human security as protection from chronic diseases, poverty, repression, and harmful disturbances in daily life patterns, whether in households, businesses, or societies. Human security is made up of seven elements, according to the UNDP: Economics, food, health, the environment, and personal life are only a few of the topics covered. 
However, the key point of human protection reverberates around the vital centre of human needs, which is the elimination of terror, desire, and, most importantly, the provision of basic needs including food, shelter, education, health, and freedom. As a result, the study's human security variables are Education, Security, Health, Economic Freedom (Personal Security), and Food.

Mohammed (2014), noted that Boko Haram is a controversial Nigerian extremist Islamic group that seeks to impose Sharia law in the Northern part of Nigeria. the group originated in Maiduguri in Borno State, located in the North East of Nigeria, around 2002. It started as a small group founded by Mohammed Yusuf (Abinbola et al, 2012). The group established an Islamic School in Maiduguri, Borno State from where it operated. The group's message of Islamic Radicalism drew the attention of prominent Islamic scholars in the region who challenged Boko Haram's interpretation of the Quran. Subsequently, the group relocated from Maiduguri in 2004 to a remote village called 'Kanama' in Yobe State where they found a base and named it Afghanistan (Ahmed, 2011).

As a small domestic religious group, Boko Haram carried out its religious propaganda and radicalization activities without disruption for about seven years. During this period, the group was considered peaceful, as there was no major provocation between it and the Nigerian government. However, the group isolated itself from the Muslim population, who did not share their ideology (Adebayo, 2014). A series of intelligence and security reports were forwarded to the government as Boko Haram gradually became more violent and anti-government.

In 2014, the group abducted two hundred schoolgirls from Chibok Local Government Area in Borno State. The abduction drew the attention of the International Community and provoked worldwide condemnation. The group further pledged allegiance to Islamic State in Iraq and Syria in 2014 to consolidate their network and gain more recognition.

The activities of the group have claimed the lives of many innocent civilians. In 2011, over 1,627 persons were killed. This conservative estimate contrasts sharply with another report which claimed that insurgency has claimed the lives of over 16,000 persons (Omonobi, 2011). The casualties are soaring very high each time they attack. The death toll is outside other estimate costs to the nation, such as the domestic property, internal displacement of persons, fracturing of family structure and damage to the country's image. Besides the destruction of lives and properties, economic activities have also been affected in Northern states, especially in those states that have witnessed or experienced attacks.

The empirical evidence, most observers said that the human capital/entrepreneurship drain is crippling the Northern economy and there are concerns that it is being transcended to the microeconomic environment. In this sense, the sect has also attacked commercial hot spots like markets, parks, government agencies and even banks in one of which they made away with N41 million, as revealed by Abu-Gada (Okereocha, 2012).

The Nigerian government initially used the carrot and stick approach to contain the group. This approach or first measure was to dock those officers that were involved in the complexity of the murder of the sect leader, Ushz Mohammed. Yusuf to appease the group. The government also accepts the carrot approach by declaring amnesty for the sect members which the leadership of the sect turned down. This mechanism would have afforded the security agents the time to further monitor and infiltrate the sect and probably dismantle it. However, all the efforts to address the problem failed as Boko Haram continued in their nefarious activities in 
the region. It was on the failure to appease the sect, that the Nigerian government, on May 14, 2013, adopted the stick measure. In this approach, the government declared a state of emergency in the three northern states of Adamawa, Borno and Yobe (Ottu, 2019).

Today, Borno State is one of the most affected states, yet, there is no empirical evidence of the magnitude of the devastation of the area by Boko Haram. The state is mentioned in the larger study of North-Eastern Nigeria. Hence, this study seeks to examine the impact of the Boko Haram insurgency on the people of Borno State, especially in the area of socio-economic development.

\section{Aim and Objectives of the Study}

This study aimed to investigate the impact of the Boko Haram insurgency on the socioeconomic development of Borno State, Northern Nigeria. Therefore, the specific objectives of the study are to:

1. To determine the impact of Boko Haram insurgency on economic activities in Borno State

2. To examine the relationship between Boko Haram insurgency and destruction of food security in Borno State.

3. To ascertain the impact of Boko Haram insurgency on the educational sector in Borno State

\section{Research Questions}

1. To what extent has the Boko Haram insurgency affected economic activities in Borno State?

2. What is the relationship between the Boko Haram insurgency and the destruction of food security in Borno State?

3. What is the relationship between the Boko Haram insurgency and the decline in the educational sector in Borno State?

\section{Research Hypotheses}

Ho1: There is no significant relationship between the Boko Haram insurgency and low economic performance in Borno State.

Ho2: There is no significant relationship between the Boko Haram insurgency and destruction in food security in Borno State.

Ho3 There is no significant relationship between the Boko Haram insurgency and the decline in the educational sector in Borno State

\section{Significance of the Study}

This study with leverage policy decisions by the Federal Government on security issues and challenges of refugees and internally displaced persons. 
The Federal and State government in Nigeria will be equipped and strengthened with knowledge from this study to understand the operations of the Boko Haram groups with a view of engaging in subsequent open (if any) and other forms of insurgency.

Defense and Strategic studies in higher institutions and training centre would benefit research which provides additional knowledge for insight in terrorism and guerrilla warfare exemplified with the Boko Haram and as different from the operations of other insurgent groups.

Researchers on counter-

insurgency would benefit from the knowledge of Boko Haram experience as they map out counter-insurgency strategies to enrich their research

\section{LITERATURE REVIEW}

\section{Theoretical Framework}

\section{Karl Marx Theory of Violence Conflict}

The conflict theory proposed by Karl Marx (1818 - 1883), looks at how certain social interactions occur through conflict as people engage every day in conflict to gain more power over others in the society. This theory has three basic tenets. The first is that conflict is a common and ongoing feature of society. In fact, conflict is the most basic feature of social life. The second tenet is that society is made up of various social groups who have conflicting values and interest. The third tenet states that all social conflicts occur between dominant and subordinate social groups who compete for resources. Karl Marx used two groups in the Conflict Theory. The Capitalist class own and control the means of production and also the distribution of goods and services. The Capitalist class is known as the dominant group. His Second class was the working class. They are the people who provide the labour necessary to produce goods and services.

The theory relates to the present study in the sense that it revealed the fact that conflict, like the Boko Haram insurgency, is built into how Nigerian society is structured and organized to the extent that inherent political, economics, injustice, poverty, diseases, exploitation and inequality generate conflict in the societies. This theory pinpoints the unjust nature of human societies, especially the exploitation and domination of one class by another as the rudiment of conflict in the society. The relevance of this theory to the present study is that it will be widely used to show how the structure of the state, economic, political and ethnic factors made the emergence of the Boko Haram insurgency and its escalation in Northern Nigeria possible.

\section{Conceptual Review}

\section{Socioeconomic Security}

Socio-economic security in this context is defined as "safety from threats of hunger, disease and repression, and protection from sudden and hurtful disruptions in the patterns of daily life - whether in homes, in jobs or communities. The UN however warned that socioeconomic security should not be equated with socioeconomic development which is grander even though they are linked. 
Furthermore, it argues that "universalism of the life claims is the common thread that binds the demands of human development today with the exigencies of development tomorrow, especially with the need for environmental preservation and regeneration for the future.

Socioeconomic security is a vague concept with no specific or universally accepted definition. Nonetheless, scholars are undisputed of the fact that it centres around the security of the economy and health. It is basically an emerging concept which seeks to tackle fundamental issues threatening human beings and to find long-lasting solutions to them as its advocates that the reference to security is the individual first, rather than the state.

\section{Boko Haram}

An expression in Hausa Language, which means, Western Education is forbidden. Hausa is a major tribe in Northern Nigeria and the Republic of Niger. The group known by the world as Boko Haram is officially called "Jama' atu Ahlissuna Lidda' Awatiwal-Jihad" an Arabic phrase meaning "people committed to the propagation of the prophet's teaching and Jihad. It is an extremist Islamic sect in the north-east Nigeria that has created havoc across the country."

The designation of the Boko Haram sect as "religious fundamentalist" was applied by conservative scholars in the early years of the $21^{\text {st }}$ century, as an organized term, though it is now widely applied to a multitude of groups outside religion, especially but not exclusively to jihadist. A defining character of the Boko Haram sect as religious fundamentalism is that it is always socially but not necessarily politically conservative (Cox, 1984) in Chibuzo and Ogaba, (2014, p. 5-6). As a religious fundamentalist, the Boko Haram group seeks an overthrow of the socioeconomic and political order by the use of various means including violence or terrorism, incremental reform of existing political regimes.

Book Haram is the product of both external and internal factors that operate in Islamic societies. The religious resurgences of Boko Haran are often further explained as a defense against outside modernity as threats to a religious group's traditional identity. The political Boko Haram exits index. The cover of religion through the activities of some disrupted politicians who engage in sponsoring terrorists to unleash attacks on opponents or to create confusion in the society. The third group consists of criminals, who hide under the cover of Boko Haram to perpetrate crimes such as bank robbery, kidnapping.

\section{Insurgency}

The term insurgency conjures often wild disparate interpretation; suffering at the hands of both experts and pundits". Commonly accepted meanings remain elusive, with predictable conceptual confusion" (Moore, 2007, P2). According to Moore (2007), the term insurgency continues to be used interchangeably, and inexactly, with warfares such as irregular warfare, unconventional warfare, revolutionary and even terrorism. He further posits that "the interchangeability of terms is understandable, given the diverse nature and adaptability of those who wage insurgency and the overlapping traits of these types of conflict" (Moore, 2007:2).

According to O'Neil (1990), insurgency is a "struggle between a non-ruling group and ruling authorities in which the nonruling group consciously uses political resources and violence to destroy, reformulate, or sustain the basis of one or more aspects of politics. The main objective of insurgency is to challenge the existing government for control; it requires the active support 
of some segment of the population;" "insurgencies do not happen if the population either supports the government or sees nothing to gain from fighting" (Curtas, 2006).

In this study, insurgency is used as a "composite conflict phenomenon which can be defined as a cellular development of resistance against the government and which expands from the initial stage of subversion-infiltration through the intermediate stage of overt resistance by small armed bands and insurrection by Boko Haram.

\section{Socio-Economic Development}

This is used in the study to refer to a monitored, manipulated or encouraged process that brings about changes in the location where people live, work and share things in common as relating to or giving consideration to both social and economic factors.

\section{Empirical Review}

Mohammed, Ibrahim and Suleiman (2017, p.67), carried out a study on the impact of the Boko Haram insurgency on Education in Adamawa State, Nigeria. the general purpose of the study was to determine the impact of the Boko Haram insurgency on education with a focus on school enrolment, school attendance and school infrastructure. The study adopted a structural equation model and was guided by three research questions. The result of the analysis indicated that human capital investment is affected by school enrolment, school attendance and school infrastructure by $71 \%, 84 \%$ and $72 \%$ as a result of any $1 \%$ increase in Boko Haram violence activity. The study further revealed that extreme religious beliefs, unemployment and illiteracy contributed to the occurrence of the Boko Haram insurgency in Adamawa State. Although this study was carried out in Adamawa State, it is nevertheless, related to the present study in the sense that both were descriptive survey studies that used the same instrument for data collection and also adopted the same descriptive statistics of mean and standard deviation in answering their research questions. More importantly, both studies were concerned, among others, with the impact of the Boko Haram insurgency on the educational aspect of human security.

In a study by Eme, et al (2012, p.54), the impact of the Boko Haram insurgency on the performance of Small-Scale Businesses in Borno State was investigated. The purpose of the study was to identify the impact of the terrorist group on the sale, income and turnover of smallscale business in the study state. The study was guided by three research questions and one null hypothesis. The result of the study revealed that the Boko Haram insurgency affects the performance of small-scale business in the area of profit turnover and patronage. This study is related to the present study in the area of the economic variable. Both studies examine the economic impact of Boko Haram activities, even though the study settings differ. Again, the study is related because both studies used descriptive survey design and questionnaire as instrument for data collection. Cronbach's Alpha method of reliability estimate was used to determine the reliability of the instrument for both studies. Above all, both studies were concerned, among others, with the impact of violent activities of the Boko Haram insurgency on the performance of small-scale business in Northern Nigeria.

Also, Kwaja (2013, p.68) conducted research on the Boko Haram insurgency and its impact on Border Security, Trade and Economic Collaboration between Nigeria and Cameroon. The objectives of the work included; identifying the major effects of Boko Haram violence activities on Border Security and Economic performance. Findings showed that the Boko Haram insurgency affects border security and also that, such violence reduce the volume of 
trade, as border traders, for fear, stayed off business along the border of Nigeria and Cameroon. The researcher recommended that both states should intensify border security, and harmonize their border security policies for effective border security.

Awortu (2015, p.54) conducted research on the socio-economic implications of Boko Haram activities in Northern Nigeria. The researcher formulated four research questions and four research objectives in line with the statement of the research problem. The finding of the result received is that the violent activities of the Boko Haram sect actually tremendously affect economic activities in Nigeria.

Lengmang (2011, p.51) carried out a study on Terrorism and the challenges of food security in the Lake Chad Region: A study of Boko Haram 2007- 2017. The purpose of the study was to find out the effect of the Boko Haram insurgency on crop cultivation, productivity, food accessibility and affordability of food products in Northern Nigeria. The result of the study showed through regression analysis the effects of Boko Haram violence on the three variables namely: crop cultivation, food availability, food accessibility and food affordability were found to be negative. Further breakdown of the study analysis showed that 5.2 million people in Northern Nigeria are severely food insecure, while over 54,000 face famine. This study is related to the current study by virtue of the fact that both studies were descriptive survey studies that used the same sampling technique to select their study sample and also used the same statistical tool to test their null hypotheses. The former study is also related to the present study because food security is also one of the variables of human security in the present study. Therefore, studies are related.

\section{METHODOLOGY}

This study was a descriptive survey and was carried out in Borno State. The population of the study consisted of all residents in Borno State. There were 5,860,182 people (2,988,693 male and 28,711,489 female) residing in Borno State which constituted the population for the study (National Bureau of Statistics, 2006). The sample size for this study was $400(\mathrm{n}=400)$. A multi-stage sampling technique was adopted in selecting the sample for the study. Firstly, stratified sampling was used to determine the senatorial districts to be sampled, then a simple random sampling technique was utilized in selecting the local government areas from each of the sampled senatorial districts for the study and finally, 3 communities were purposively selected from the sampled local governments areas to select respondents for the study.

The instruments for data collection were a questionnaire and a focus group discussion guide. A standardized questionnaire title, "Impact of Boko Haram Insurgency on Socioeconomic Development Questionnaire" was used as the instrument of the study. The instrument consisted of two sections; A and B. Section A elicited socio-demographic information from the respondents, while section $B$, information on the impact of the Boko Haram insurgency on socioeconomic development in Borno State. A total of 400 copies of questionnaires were administered to the respondents. While 387 copies were completed and retrieved, thirteen (13) copies of the questionnaires were not returned by the respondents.

The adopted questionnaire was subjected to face and content validation. The instruments were validated by the research supervisor and three experts from the Department of Political Science, University of Port Harcourt. It was subjected to modification for the current study. To 
ensure the reliability of the instrument, a trial test was conducted. The trial test was carried out using 30 respondents comprising 15 civilians and 15 security officers from the Niger-Delta States of Rivers and Bayelsa. The overall reliability coefficient for the entire instrument yielded (0.04). This high-reliability index indicated that the instrument was reliable. Data was collected and analyzed using the statistical package for social science (SPSS) version 23.0 using descriptive statistical tools were utilized to analyze the socio-demographic factors of respondents and answering the research questions, whilst inferential statistical tool such as the simple regression at 0.05 level of significance was employed to test the hypothesis.

\section{RESULTS AND DISCUSSION OF FINDINGS}

\section{SECTION A: Socio-Demographic Factors of Respondents}

\section{Socio-demographic Characteristics}

\section{Gender}

Male

Female

Total

Age

21-30

$31-40$

41-50

51-60

61-Above

Total

Level of Education

Formal education

Quaranine education

Man-formal education

Total

Occupation

Security Officers

Community Leaders

Political Leaders

Civil Servants

Others

Total

\section{Frequency (F)}

Percentage \%

250

64.5

137

387

35.6

100.0

17

100

4.3

140

25.8

70

36.1

60

18.0

387

15.5

100.0

268

69.2

100

19

25.8

4.9

387

100.0

98

25.3

67

17.3

48

12.4

100

25.8

80

20.7

387

100.0 


\section{SECTION B: Research Questions}

Research Question 1: To what extent has the Boko Haram insurgency affected economic activities in Borno State?

Table 2: Effect of Boko Haram insurgency on economic activities in Borno State

\begin{tabular}{|c|c|c|c|c|c|c|c|c|}
\hline SN & Items & SA (\%) & $\mathrm{A}(\%)$ & $\mathrm{D}(\%)$ & SD (\%) & Mean & SD & Decision \\
\hline 1 & $\begin{array}{l}\text { Boko Haram } \\
\text { insurgency has not } \\
\text { affected market } \\
\text { activities in Borno } \\
\text { State }\end{array}$ & $36(9.3)$ & $55(14.2)$ & $126(32.6)$ & 170(43.9) & 1.89 & \pm .97 & Disagreed \\
\hline 2 & $\begin{array}{l}\text { The violent activities } \\
\text { of the Boko Haram } \\
\text { insurgency have not } \\
\text { affected banking } \\
\text { services in Borno } \\
\text { State. }\end{array}$ & $30(7.8)$ & $31(8.0)$ & $136(35.1)$ & 190(49.1) & 1.74 & \pm .90 & Disagreed \\
\hline 3 & $\begin{array}{l}\text { Boko Haram } \\
\text { insurgency has not } \\
\text { affected street trading } \\
\text { in Borno State }\end{array}$ & $29(7.5)$ & $35(9.0)$ & $134(34.6)$ & 189(48.6) & 1.75 & \pm .91 & Disagreed \\
\hline & Grand mean & & & & & 1.79 & \pm .93 & Disagreed \\
\hline
\end{tabular}

Table 2 shows the responses derived from the respondents in Borno State on the effect of the Boko Haram insurgency on economic activities in Borno State. From the table, it was observed that the respondents disagreed with all the items enumerated. Based on the responses, a grand mean $=1.79$ was derived which is lower than the criterion mean $=2.5$. This entails that the emergence and operations of the Boko Haram insurgency in Borno State have affected the economic activities of the state detrimentally. The highest proportion of each of the item showed that $170(43.9 \%)$ of the respondents strongly disagreed that to the notion that the Boko Haram insurgency has not affected market activities in Borno State. Also, 190(49.1\%) of the respondents strongly disagreed that the violent activities of the Boko Haram insurgency have not affected banking services in Borno State.

Research Question 2: What is the relationship between the Boko Haram insurgency and the destruction of food security in Borno State? 
Table 3: Relationship between Boko Haram insurgency and destruction of food security in Borno State

\begin{tabular}{|c|c|c|c|c|c|c|c|c|}
\hline $\mathbf{S N}$ & Items & SA (\%) & $\mathrm{A}(\%)$ & $\mathrm{D}(\%)$ & SD (\%) & Mean & SD & Decision \\
\hline 1 & $\begin{array}{l}\text { The violent activities of the } \\
\text { Boko Haram insurgency } \\
\text { and subsequent destruction } \\
\text { of food crops led to food } \\
\text { insecurity in the state? }\end{array}$ & $27(7.0)$ & $27(7.0)$ & $153(39.5)$ & $180(46.5)$ & 1.74 & \pm .87 & Disagreed \\
\hline 2 & $\begin{array}{l}\text { The killing of farmers by } \\
\text { the Boko Haram sect has } \\
\text { affected food production in } \\
\text { Borno State? }\end{array}$ & $37(9.6)$ & $38(9.8)$ & $125(32.3)$ & $187(48.3)$ & 1.81 & \pm .96 & Disagreed \\
\hline 3 & $\begin{array}{l}\text { Looting of food } \\
\text { storehouses by the Boko } \\
\text { Haram insurgents is greatly } \\
\text { responsible for food } \\
\text { instability in Borno State? }\end{array}$ & $35(9.0)$ & $35(9.0)$ & $141(36.4)$ & $176(45.5)$ & 1.81 & \pm .94 & Disagreed \\
\hline & Grand mean & & & & & 1.79 & \pm .92 & Disagreed \\
\hline
\end{tabular}

Table 3 displays the responses derived from the respondents in Borno State on the effect of the Boko Haram insurgency on the destruction of food security in Borno State. From the table, it was observed that the respondents disagreed with all the items enumerated. Based on the responses, a grand mean $=1.79$ was derived which is lesser than the criterion mean $=2.5$. This entails that the emergence and operations of the Boko Haram insurgency in Borno State have disrupted the food security of the state deleteriously. The highest proportion of each of the item showed that $180(46.5 \%)$ of the respondents strongly disagreed with the item which says that the violent activities of the Boko Haram insurgency and subsequent destruction of food crops led to food insecurity in the state. Also, 187(48.3\%) of the respondents strongly disagreed that the killing of farmers by the Boko Haram sect has affected food production in Borno State.

Research Question 3: What is the relationship between the Boko Haram insurgency and the decline in the educational sector in Borno State? 
Table 4: Relationship between Boko Haram insurgency and decline in the educational sector in Borno State

\begin{tabular}{|c|c|c|c|c|c|c|c|c|}
\hline $\mathbf{S N}$ & Items & SA (\%) & A (\%) & $\mathrm{D}(\%)$ & SD (\%) & Mean & SD & Decision \\
\hline 1 & $\begin{array}{l}\text { Closing of schools } \\
\text { because of Boko } \\
\text { Haram insurgency } \\
\text { has not affected } \\
\text { education in Borno } \\
\text { State }\end{array}$ & $29(7.5)$ & $30(7.8)$ & $149(38.5)$ & $179(46.3)$ & 1.76 & \pm .89 & Disagreed \\
\hline 2 & $\begin{array}{l}\text { The present attacks } \\
\text { and the destruction of } \\
\text { school buildings have } \\
\text { not affected teaching } \\
\text { and learning in Borno } \\
\text { State. }\end{array}$ & $32(8.2)$ & $32(8.2)$ & $145(37.5)$ & $178(46.0)$ & 1.79 & \pm .91 & Disagreed \\
\hline 3 & $\begin{array}{l}\text { The killing of } \\
\text { teachers, students and } \\
\text { abduction of students } \\
\text { by Boko Haram } \\
\text { insurgents has not } \\
\text { reduced school } \\
\text { enrollment in Borno } \\
\text { State }\end{array}$ & $42(10.9)$ & $42(10.9)$ & $133(34.4)$ & $170(43.9)$ & 1.89 & \pm .96 & Disagreed \\
\hline & Grand mean & & & & & 1.81 & \pm .92 & Disagreed \\
\hline
\end{tabular}

Table 4 displays the responses derived from the respondents in Borno State on the relationship between Boko Haram insurgency and decline in the educational sector in Borno State. From the table, it was observed that the respondents disagreed with all the items enumerated. Based on the responses, a grand mean $=1.81$ was derived which is lesser than the criterion mean $=$ 2.5. This entails that the Boko Haram insurgency has had a destructive impact on the educational sector of Borno State. The highest proportion of each of the item showed that $179(46.3 \%)$ of the respondents strongly disagreed with the item which says that closing of schools because of Boko Haram insurgency has not affected education in Borno State; whilst, only $32(8.2 \%)$ of the respondents strongly agreed that the present attacks and the destruction of school buildings have not affected teaching and learning in Borno State. 


\section{Test of Hypothesis}

Hypothesis 1: There is no significant relationship between the Boko Haram insurgency and low economic performance in Borno State.

Table 5: Simple Regression on the relationship between Boko Haram insurgency and low economic performance

\begin{tabular}{llllllll}
\hline Model & $\begin{array}{l}\text { Sum of } \\
\text { Squares }\end{array}$ & Df & $\begin{array}{l}\text { Mean } \\
\text { Square }\end{array}$ & R & $R^{2}$ & p-value & Decision \\
\hline Regression & .136 & 1 & .136 & .019 & .000 & .017 & Rejected \\
Residual & 396.118 & 385 & 1.029 & & & & \\
Total & 396.253 & 386 & & & & & \\
$* S=$ Significant $p<0.05$ & & & & &
\end{tabular}

Table 5 shows the regression analysis on the correlation between the Boko Haram insurgency and low economic performance in Borno State. The result of the study shows a regression coefficient of .019 indicating a weak positive relationship between the Boko Haram insurgency and the low economic performance in Borno State. The null hypothesis which states that there is no significant relationship between Boko Haram insurgency and low economic performance in Borno State was rejected and the alternate hypothesis upheld $(\mathrm{p}=(0.071)<0.05)$. Thus, it can be concluded that the activities of the Boko Haram insurgency have caused disparaging impacts on the economy of Borno State.

Hypothesis 2: There is no significant relationship between Boko Haram insurgency and destruction in food security in Borno State.

Table 6 Simple Regression on the relationship between Boko Haram insurgency and destruction in food security.

\begin{tabular}{llllllll}
\hline Model & $\begin{array}{l}\text { Sum of } \\
\text { Squares }\end{array}$ & Df & $\begin{array}{l}\text { Mean } \\
\text { Square }\end{array}$ & R & $R^{2}$ & p-value & Decision \\
\hline Regression & .036 & 1 & .036 & .010 & .000 & .043 & Rejected \\
Residual & 358.429 & 385 & .931 & & & & \\
Total & 358.465 & 386 & & & & & \\
\hline
\end{tabular}

$* S=$ Significant $p<0.05$

Table 6 shows the regression analysis on the correlation between Boko Haram insurgency and destruction in food security in Borno State. The result of the study shows a regression coefficient of .010 indicating a weak positive relationship between Boko Haram insurgency and destruction in food security in Borno State. The null hypothesis which states that there is no significant relationship between Boko Haram insurgency and destruction in food security in Borno State was rejected and the alternate hypothesis upheld $(\mathrm{p}=(0.071)<0.05)$. Hence, it can be concluded that the activities of the Boko Haram insurgency have caused destruction in food security in Borno State. 
Hypothesis 3: There is no significant relationship between the Boko Haram insurgency and the decline in the educational sector in Borno State.

Table 7: Simple Regression on the relationship between Boko Haram insurgency and decline in the educational sector.

\begin{tabular}{llllllll}
\hline Model & $\begin{array}{l}\text { Sum of } \\
\text { Squares }\end{array}$ & Df & $\begin{array}{l}\text { Mean } \\
\text { Square }\end{array}$ & R & $R^{2}$ & p-value & Decision \\
\hline Regression & 5.964 & 1 & 5.964 & .140 & .020 & .006 & Rejected \\
Residual & 297.638 & 385 & .773 & & & & \\
Total & 303.602 & 386 & & & & & \\
\hline
\end{tabular}

*S= Significant $p<0.05$

Table 7 shows the regression analysis on the relationship between Boko Haram insurgency and decline in the educational sector in Borno State. The result of the study shows a regression coefficient of .140 indicating that there exists a strong positive relationship between Boko Haram insurgency and decline in the educational sector in Borno State. The null hypothesis which states that there is no significant relationship between Boko Haram insurgency and decline in the educational sector in Borno State was rejected and the alternate hypothesis upheld $(\mathrm{p}=(0.006)<0.05)$. Thus, it can be concluded that the activities of the Boko Haram insurgency have disparaged the educational sector in Borno State.

\section{CONCLUSION}

Boko Haran's insurgency has become a dangerous multifaceted problem. Although it initially emerged as a localized Nigerian problem, it has over time transformed into a regional threat. It is therefore evident that as the Boko Haram insurgency has claimed lots of lives, aggravated the food and nutrition insecurity, further damaged to health and education sector, and has caused general fear and anxiety; an urgent solution is needed. The situation, therefore, demands the political will and the articulation of a comprehensive strategy to address its root causes and dangerous dynamics, focusing on a soft approach that could erode the appeal of Boko Haran's insidious ideology. Inhibit opportunities for recruitment and radicalization, and choke its financial windpipe. To this end, the following actionable recommendations will be critical to addressing the effects of the Boko Haram insurgency on human security and to defusing the threat.

\section{RECOMMENDATIONS TO ADDRESS BOKO HARAM INSURGENCY}

1. Create job opportunities for young people: Whether in Nigeria where the Boko Haram group originated or in neighbouring countries of Cameroon, Chad and Niger where it has found a recruitment pool, limited opportunities for legitimate livelihood have made young people more vulnerable and hence more intrigued in joining insurgent groups. Thus, robust and targeted interventions to create jobs in Nigeria, particularly in Borno State, and amongst the border communities of neighbouring states, should form a key priority of the 
government. This will put more youths in employment and help dry up Boko Haram's recruiting base. Achieving this will require clamping down on corruption to free up enough resources for the interventions that are desperately needed in this area.

2. Protecting and strengthening human security: The Nigerian military has too often taken civilian casualties too easy into account. By killing citizens in the North, the population's frustration against the military increases, thereby increasing Boko Haram's appeal as an alternative. The government should rather put its focus on the protection of civilians, witnesses and key peacemakers such as moderate Imams who preach against the insurgency. Therefore, the Nigerian military and militaries of neighbouring countries should shift their focus from retaliation attacks to improved defensive and intelligence measures. In addition, Nigeria needs to step up its governance capacity by improving traditional state services such as health, transport and social protection for its citizens. By increasing the legitimacy of the government, Boko Haram will lose its constituency in the long run.

3. Rollout counter-violent extremism programmes: Nigeria, in partnership with her neighbours and the international community should evolve and support region-wide counter-violent extremism advocacy. Such an ideological operation should be robustly framed in Arabic, Hausa, and Kanuri languages, and in the respect of cultures and traditions, to debunk Boko Haram ideology, narratives and messages, thereby making it difficult for the group to recruit from citizens in the region.

4. Improving the human rights record of the security forces: There is an urgent need for robust, targeted training as well as capacity building for military and security forces so as to improve their human rights record in counter-insurgency operations. It is crucial for the military to understand that human rights violations hamper the success of its efforts and increase the appeal of the Boko Haram insurgency. This recognition and improved training could boost public confidence in the Nigerian security forces, thus encouraging citizens to share information on the insurgents and their collaborators.

\section{REFERENCES}

Abimbola, J. O., \& Adesote, S. A. (2014). Domestic terrorism and Boko Haram insurgency in Nigeria, issues and trends: Journal of Arts and Contemporary Society. 4(2), 2-13.

Adams, D. (2014). Ethnic and regional violence in Nigeria: Implications for national security. Journal of Politics and Law. 7(1), 3-11.

Adebayo, A. A. (2014). Implications of 'Boko Haram' terrorism on national development in Nigeria. Mediterranean Journal of Social Sciences. 5 (3), 123.

Agbiboa, D., \& Maiangwa, B. (2014). Nigeria united in grief; divided in response: Religious terrorism, Boko Haram and the dynamics of state response. African Journal on Conflict Resolution. 14(2), 11-12.

Ahmed, K. (2011). There is a solution but does the will exit? Daily Trust.

fromhttp://www.workersalternative.com/national-issues/11-hungerin-nigeria.'

Awortu, B. E. (2015). Boko Haram Insurgency and the Underdevelopment of Nigeria.

Research on Humanities and Social Sciences. 5(6), 15-17.

Chibuzo, M., \& Ogada, A. (2012), "Violence and threat to Yobe's Economic Growth," The Moment. 
Cox, T. (1984), Why men rebel, Princeton. Princeton University Press

Curtas, O. (1999). Social costs of poverty: The case of crime in Nigeria. Journal of Social Development in Africa. 14(3), 5-18

Danjibo, N. D. (2012). Islamic fundamentalism and sectarian violence. The 'Maitatsine' and 'Boko Haram' crises in Northern Nigeria. Peace and Conflict Studies Paper Series, Institute of African Studies, University of Ibadan.

Eme, O. I., \& Ibietan, J. (2012). The cost of Boko Haram activities in Nigeria. Arabian Journal of Business and Management Review. 2 (2), 13-16.

Kwaja, C. (2013). Rethinking insurgencies and state failure. http://www.ssrresourcecentre.org /2013/09/30/rethinkinginsurgencies-and-state-failure-in-nigeria.

Lengmang, J. (2011). "The upsurge of religious fundamentalism: A critical reflection in the light of the 'Boko Haram' phenomenon in Northern Nigeria'. John Archers Publishers.

Mohammed, M., Ibrahim, N., \& Suliman, N. (2017). Curbing violence in Nigeria (II): The Boko Haram insurgency. ICG Africa Report No. 216.

Moore, C.A. (1978). Political Studies. Eastover. McDonalds and Evans

Okereocha, C. (2012). "Heartache for the economy", TELL, pp. $46-47$

Omonobi, K. (2011). "Boko Haram and other security challenges before Jonathan", Vanguard.

O' Niel, J. (1990). Poverty and Civil War: What Policy Makers Need to Know. The Brookings Institution, Massachusetts.

Ottu, M. (2019) "How to end Boko Haram Fire-Back" http://thewillnigeria.com/ opinion /897

UNICEF. (2018). More than 1,000 children in northeastern Nigeria abducted by Boko Haram since 2013. http://www.unicef.org/wca/press-releases/more-1000-childrennortheastern-nigeria-abducted-boko-haram-2013 